NEJE

21,1

Received 6 April 2018 Revised 25 April 2018 27 April 2018 Accepted 3 May 2018

\section{INVITED PAPER Founding team experience, industry context, and new venture creation}

\author{
Jun Li and Dev K. Dutta \\ Department of Management, \\ University of New Hampshire Peter T. Paul College of Business and Economics, \\ Durham, New Hampshire, USA
}

\begin{abstract}
Purpose - The purpose of this paper is to examine the role of founding team experience (industry and venturing) in new venture creation. This paper posits the following questions: How does founding team experience influence the likelihood of new venture creation, in the nascent stage? How does industry context moderate this relationship? The study aims to fill an important gap in the literature by unpacking the impact of different types of founding team experiences on venture outcome, and by focusing on the influence of founding team in the venture creation process, specifically at the nascent stage.

Design/methodology/approach - The paper utilizes data from the Second Panel Study of Entrepreneurial Dynamics, a longitudinal data set of 1,214 nascent entrepreneurs in the USA. Logistics regression was employed to analyze the effect of founding team experience on new venture creation. Post hoc analysis was conducted to ensure the confidence of the findings.

Findings - The paper provides empirical insights about how founding team experience influences the likelihood of new venture creation in the nascent stage. At the nascent stage, founding team industry experience positively affects new venture creation while founding team venturing experience does not. However, in the high-technology industry environment, the influence of the founding team's venturing experience on new venture creation is stronger than that in the low-technology industry environment.

Research limitations/implications - Due to the design of the data set, there is a risk of "right-censoring" problem. Also, because the study used archival data on founding teams, the methodology did not allow for uncovering the underlying team processes and dynamics during the venture creation process based on learning from experience. Future studies are encouraged to examine other types of founding team experience and the underlying process-level factors on venture creation.

Practical implications - The paper provides important practical implications for nascent entrepreneurs/entrepreneurial teams on team assembling and composition. In general, a team with higher-level industry experience is critical for venturing success. A team with higher-level venturing experience is more desired in the high-technology industry.

Originality/value - This paper fulfills an important gap in the entrepreneurial team literature by highlighting the complex and nuanced ways in which founding team experience influences the likelihood of venture creation in the nascent stage of the firm, especially after incorporating the additional impact of the industry context.
\end{abstract}

Keywords Founding team experience, Nascent stage, New venture creation

Paper type Research paper

\section{Introduction}

Creating a new business requires significant knowledge about an emerging opportunity, market, product/service and associated organizational processes, all of which rarely reside in one person. Therefore, even though solo entrepreneurship is always appreciated, the idea of the entrepreneur as the "lonely hero" (Chowdhury, 2005) is increasingly being replaced by

\footnotetext{
(C) Jun Li and Dev K. Dutta. Published in the New England Journal of Entrepreneurship. Published by Emerald Publishing Limited. This article is published under the Creative Commons Attribution (CC BY 4.0) licence. Anyone may reproduce, distribute, translate and create derivative works of this article (for both commercial and non-commercial purposes), subject to full attribution to the original publication and authors. The full terms of this licence may be seen at http://creativecommons.org/licences/by/4.0/legalcode
} 
the notion of an entrepreneurial founding team. In the past two decades, considerable Founding team research has been conducted on entrepreneurial teams (also referred to as founding teams or new venture teams) (see Klotz et al., 2014 for a review). Scholars have examined a variety of founding team characteristics and their influence on new venture performance and/or other firm outcomes, such as founding team composition (Jin et al., 2017), team demographic diversities (Chowdhury, 2005), team social interactions (Lechler, 2001), team personalities (Zhou et al., 2015) and so on. However, the extant research has largely tended to focus on the impact of founding teams on outcomes for a venture already created. In contrast, research on the likely impact of founding teams on venture creation is still at its infancy (Muñoz-Bullon et al., 2015):

$R Q 1$. How does founding team experience influence the likelihood of new venture creation, in the nascent stage?

RQ2. Are there other contingencies that affect this relationship?

These are the two main research questions guiding this study. Specifically, the study examines two types of founding team experience: industry and venturing experiences, and their effects on the likelihood of venture creation, after taking into account the industry context. New venture creation is a non-routine, risky and complex process, which requires founders to engage in a range of processes: scanning the environment, selecting opportunities and formulating strategies to take advantages of these opportunities (Chandler and Hanks, 1994). For ventures that are team driven, the process should benefit from team-based experiences (Delmar and Shane, 2006; Muñoz-Bullon et al, 2015; Zheng, 2012). Yet, studies on how founding team experience influences the new venture creation process are sparse. The extant literature on founding team experience has tended to emphasize the team's role and impact in a variety of venture outcomes, such as survival, growth, performance and other organizational/strategic outcomes (e.g. Beckman et al, 2007; Colombo and Grilli, 2005; Delmar and Shane, 2006; Fern et al., 2012; Zheng et al., 2016). In spite of an early and definitive call about two decades ago for more research on the role of founding teams in venture creation (Kamm et al, 1990), limited attention has been paid on this topic. This study attempts to fill this important gap.

Furthermore, entrepreneurial scholars have long argued the importance of the actual context in researching the impact of entrepreneurs and/or entrepreneurial teams (e.g. Ensley et al., 2006; Hmieleski and Ensley, 2007; Lumpkin and Dess, 2001). It is conceivable that the likely impact of founding team experiences on venture creation may vary, depending on founding conditions. As such, the present study examines the moderating effect of one important founding condition, the industry context. The authors argue that the effect of founding team experience on venture creation may vary, depending on whether the industry context is high tech or low tech. Related to this is another fundamental question of this study: founding team often brings different forms of experiences to the venturing process (this study looks at two types: industry and venturing). Therefore, are these experiences similar in terms of their impact on the likelihood of venture creation? If not, under which circumstances, does one type of founding team experiences become more important than the other, during the venture creation process?

This paper makes several contributions. First, as already noted, previous studies have largely investigated new venture teams' (often times the top management teams' (TMTs)) impact on established ventures (e.g. Amason et al., 2006; Ensley and Hmieleski, 2005; Ensley et al., 2002; Hmieleski and Ensley, 2007; Zhao et al., 2013). In this regard, this study is especially salient in understanding how entrepreneurial team experiences affect the continuation or discontinuation of a venture gestation process leading to a firm formation. Second, most of the studies on entrepreneurial experiences have either looked at entrepreneurs' or founding teams' prior founding experience (Wright et al., 1998), or treated as a unified measure of work experience (e.g. Reuber and Fischer, 1999). This study unpacks 
NEJE

21,1

the different type of founding team experiences and further explores their interaction effects with the context the venture is placed in, thus offering a more fine-grained perspective on the impact of founding team experience on the likelihood of new venture creation.

Building upon the entrepreneurial cognition perspective (Mitchell et al., 2002) and the upper echelons theory (Hambrick and Mason, 1984), this study posits that the founding team industry and venturing experiences are beneficial to new venture creation. Additionally, the study suggests that the impact of founding team experiences on the likelihood of new venture creation will be stronger in a high-technology industry than that in a low-technology industry. Hypotheses were tested using a unique longitudinal data set of the Second Panel Study of Entrepreneurial Dynamics (PSED II) (Gartner and Shaver, 2012).

The paper is organized as follows. The first section reviews and discusses the literature on founding team experiences and new venture creation. The next section hypothesizes the independent effects of founding team experiences on new venture formation, as well as the moderating effects of industrial environment, followed by research methodology and results. Implications for practitioners and future research were presented at the end.

\section{Theory and hypotheses development}

Venture creation is a complex, non-routine process, which involves interaction among various agents (individuals, partners, groups, parent organizations, etc.) and the business environment. The process is characterized by four properties, namely, intentionality, resources, boundary and exchange (Katz and Gartner, 1988). Specifically, intention is referred to as the process of seeking information to achieve the goals of creating an organization; resources, for the process of resource acquisition and combination process to form an organization; boundary identification, for setting up tax system, legal forms; and finally exchange for activities within (i.e. human recourse management) and across the organizational boundary (i.e. selling goods to customers, etc.). Therefore, for an emerging organization to be called as an established entity, the venture needs to be able to successfully demonstrate and integrate these activities. Among these activities, opportunity identification has been considered as one of the most essential part of this process. Essentially, entrepreneurial outcomes such as new venture creation, at least in part, happen based on the different capabilities of entrepreneurs to identify potentially profitable opportunities (Shane and Venkataraman, 2000; Shepherd and DeTienne, 2005).

This study draws insights from two theories of entrepreneurship to analyze the founding team experiences' role in new venture creation. The first is the entrepreneurial cognition theory (Mitchell et al., 2002), and the other is the upper echelons theory (Hambrick and Mason, 1984). The entrepreneurial cognition perspective views new venture creation as a cognitive process in which founders/founding teams use their "knowledge structures [...] to make assessments, judgments, or decisions involving opportunity evaluation, venture creation, and growth" (Mitchell et al., 2002, p. 97). The entrepreneurial cognitive perspective is especially suited to understanding the process of new venture creation because of two reasons: first, the process of forming a new venture involves high level of uncertainty, ambiguity and risks; and second, the impact of founders/founding team's managerial cognitions is stronger in this process, than those of large, established firms (Forbes, 1999). According to this perspective, two key elements of entrepreneurial cognition: the entrepreneurs' knowledge structure (heuristical or scripted) and decision making (Mitchell et al., 2007) directly influence choices made by the founders/founding team during the venturing process. Entrepreneurs are found to be more likely to rely on their biases and heuristics in decision making (Busenitz and Barney, 1997). Indeed, entrepreneurship has been characterized as an "enactment" process where acting precedes systematic thinking (Gartner et al., 1992). Similarly, scholars argue 
that mental heuristics ("shortcuts") and knowledge acquired from past experience are Founding team often used by entrepreneurs in their venturing process (Baron, 2008).

The upper echelons theory argues that the cognitive capacity of the TMT typically represents the dominant heuristics of the firm (Hambrick and Mason, 1984). Managers develop their heuristics from their career experiences (Hambrick and Mason, 1984). As Hambrick and Mason (1984, p. 200) suggested, "executives' career experiences partially shape the lenses through which they view current strategic opportunities and problems." Managers' career experiences expose them to specific problems and situations. Managers may carry "imprints" from their past career experiences (Stinchcombe and March, 1965). Simplifying heuristics are developed from such experiences to allow managers to arrive at satisfying solutions with limited search (March and Simon, 1958; Simon, 1979). Compared to this managerial cognition, entrepreneurial cognition is more based upon entrepreneurs' experiences and belief, as organizational structure and system are far from developed yet (Alvarez and Busenitz, 2001).

This study focuses on one important attribute of the founding team-their prior experiences. Founding team experience is usually taken to comprise the following categories: industry experience (or knowledge of the specific industry the venture is being launched in), venturing experience (or knowledge about creating and managing entrepreneurial new ventures) and managerial experience (or knowledge of managing businesses, in general) (West and Noel, 2009). This study considers two types of founding team experience (industry and venturing experience) and examines how they affect the likelihood of venture creation. With regard to managerial experience, there is a fair level of consensus that such general managerial experience does not contribute to the success of new ventures (Colombo and Grilli, 2005; Sandner et al, 2008) unless little industry-specific managerial knowledge is available in the industry where the venture is being created (Patzelt et al, 2008). As such, the present research focuses only on the impact of founding team industry and venturing experience.

\section{Founding team industry experience}

Entrepreneurship literature has long emphasized the role of founders' personal characteristics in influencing new venture creation, growth and performance (e.g. Chandler and Hanks, 1994; Colombo and Grilli, 2005; Cooper et al., 1994). As one important form of human capital (Becker, 1962), the founder's work experience is presumed to have significant influence on both the creation and the performance of new ventures.

This study first examines one specific form of founding team prior work experience-their experiences with the industry in which the proposed new venture is going to compete in. Previous studies have mostly focused on founders' startup or venturing experience (Wright et al., 1998). The authors think industry experience is critically important in the venturing process. From an entrepreneurial cognition perspective, founders are primed to identify those opportunities that reflect their prior industry experience (Shane and Venkataraman, 2000). In general, experience increases founders' entrepreneurial alertness - an ability to detect opportunities which are overlooked by others (Kirzner, 1979) and such alertness often comes from a person's prior knowledge and prior industry experience (Casson, 1987). Tang et al. (2012) found that entrepreneurs prior knowledge significantly increases three dimensions of entrepreneurial alertness: scanning and searching for new information, connecting previously disparate information and evaluating whether the new information represents an opportunity. Managers with industry experience in a high uncertain entrepreneurial environment are more able to identify and seize new opportunities (Kor, 2003). In a longitudinal study on academic spinoff ventures, Rasmussen et al. (2011) discovered that industry experience embedded in the entrepreneurial team allows the team to be able to frame and revise the scientific knowledge into a viable business opportunity. 
NEJE

21,1

Furthermore, scholars have found that founding teams with more diverse industry experience identify a larger number of, and in particular, more varied (distant) market opportunities (Gruber et al., 2012). It is expected that a founding team with more industry experience will be more able to detect new opportunities, which may have been overlooked by others.

When making strategic decisions in new ventures, an entrepreneur tends to draw on content knowledge that is readily accessible in his or her memory (Fern et al., 2012). Although it may be difficult to attribute nascent ventures to industry settings as they are still in the emerging stage, prior industry experience equips the team with better information which, in turn, reduces founders' perceived risks (Norton and Moore, 2006) and lowers their expectations of liabilities of newness (Gimeno et al., 1997; Shane and Khurana, 2003). Industry experience provides knowledge and important information about the industry norms, rules and practices in the environment in which the new venture is going to operate. Founding team with more industry experience is able to understand customer better and knows how to serve them (Delmar and Shane, 2006). In the similar vein, industry information with regard to the interactions among suppliers, customers, regulators and the market enables the founding team necessary knowledge to secure relevant resources and organize venturing activities. Scholars argue that industry-specific experience shapes entrepreneurs' subjective entrepreneurial knowledge (Kor et al., 2007). Founders with little industry experience are more limited in the range of expertise and competence they can draw upon (Wasserman, 2003).

Additionally, entrepreneur's prior professional experience such as industry experience not only contributes to "what you know," it can also contribute to "who you know" (Hsu, 2007, p. 724). In matter of fact, entrepreneur's industry experience is often viewed as a great asset for an entrepreneur (Brush et al., 2001) and is valued by potential investors such as venture capitalists in making investment decisions (MacMillan et al., 1985). Founders or founding teams with industry experience can take advantage of their social ties that have been formed in the focal industry to obtain legitimacy and commitments from existing business partners for their new businesses (Delmar and Shane, 2006). In fact, scholars find that experienced founders engage in more legitimacy-seeking behaviors (Perry et al., 2011). Studies also find that prior industry-specific experiences positively influence the likelihood of obtaining venture finance (Eckhardt et al., 2006). In sum, the external connections derived from industry experience can be an invaluable capital for a nascent venture as they help bridge the founders/ founding teams with critical resource providers (Burt, 2009; Shane and Stuart, 2002).

The above arguments lead to the following hypothesis:

H1. Founding team industry experience increases the likelihood of new venture creation.

\section{Founding team venturing experience}

Founding team venturing experience refers to a founding team's prior experience in being involved with venturing initiatives, or owning a private business (Wright et al., 1998). In a field study investigating successful new ventures' profiles, Duchesneau and Gartner (1990) found that one of the successful new ventures' profile is that entrepreneurs have prior venturing experience. Venturing itself is a lived experience (Morris, 2015) in which entrepreneurs are shaped and created by venturing events (Morris et al., 2012). Scholars have argued that prior entrepreneurial experience enhances the number of opportunity identifications (Gruber et al., 2012; Westhead et al., 2009). In exploring the antecedents of entrepreneurial cognition of habitat (experienced) entrepreneurs, scholars have asked whether experienced entrepreneur presents unique cognitive patterns or characteristics during their venturing process than novice entrepreneurs (Grégoire et al., 2011; Ucbasaran et al., 2008). Grégoire et al. (2010), for example, found that experienced entrepreneurs used prior knowledge 
to allow them to identify new patterns of meaning and draw the entrepreneurial implications of these patterns. Similarly, Forbes (2005) suggested that entrepreneurs are not homogeneous in their cognitive patterns and such differences can be explained (at least partially) by their prior entrepreneurship experiences. Zhao et al. (2005) found that entrepreneurial experience is experience positively related to entrepreneurial self-efficacy - that is, the entrepreneur's belief in their ability to successfully launch an entrepreneurial venture, an important antecedent to entrepreneurial intention.

From a decision-making perspective, a pre-ownership experience in a highly similar business helps the founder (or founding teams) to better understand the customers, suppliers and competitors associated with the specific industrial environment (Chandler, 1996). Besides, non-routined entrepreneurial events contribute to entrepreneurs' stock of knowledge (Reuber and Fischer, 1999). Venturing experience provides the venture with skills and expertise in organizing, coordinating, planning and motivating people (Chandler and Jansen, 1992; Reuber and Fischer, 1994). In a study comparing experienced (serial) entrepreneurs and novice entrepreneurs, Baron and Ensley (2006) found that serial entrepreneurs tend to think about opportunities in more sophisticated and pragmatic ways from a business-model point view than novice entrepreneurs, allowing them be more effective in acting on identified business opportunities and making decisions. When facing a complex decision, such as decisions in the venturing process, experienced entrepreneurs are expected to theorize more from their own experiences, and to be more likely to go beyond the information given to them in a decision problem (Dew et al., 2009). In a highly ambiguous and uncertain venturing environment, lack of entrepreneurial experience may lead to more mistakes in decision making.

In addition, prior venturing experience sends a positive signal about the credentials of the founder or the founding teams to the potential investors, especially VCs (Hsu, 2004, 2007). Besides, founding teams with prior venturing experience have wider social network and are more effective to develop new ones (Mosey and Wright, 2007). These types of social capital are critical for the founding team to harness necessary legitimacy and resources for new venture creation (Blatt, 2009).

The above arguments lead to the following hypothesis:

H2. Founding team venturing experience is positively related to the likelihood of new venture creation.

\section{The moderating effect of industry context}

Entrepreneurs do not operate in a vacuum, they work within the environment surrounding them (Gartner, 1985). In responding to uncertain founding conditions, the founding team needs to explore various options, evaluate diverse scenarios and generate a more comprehensive solution. Researchers have long been interested in the effect of the objective characteristics of the environment (from a contingency point of view) or the perceived environment by entrepreneurs (from a cognitive perspective) on entrepreneurs' entrepreneurial intentions and activities (Edelman and Yli-Renko, 2010). Industrial organization economists consider that a firm's industry environment has deterministic impact on firm performance (Porter, 1985). Organization ecologists consider a firm's industry environment as one of the most important founding conditions, critically influencing organizational mortality (Swaminathan, 1996). Scholars from cognitive perspective have examined how entrepreneurs view their founding environment and construct their cognitive framing through the venture creation process (e.g. Edelman and Yli-Renko, 2010; Hmieleski and Baron, 2009; McMullen and Shepherd, 2006; Shaver and Scott, 1992).

The following section examines the moderating effect of the nascent venture's industry on the relationships between founding team experience and the likelihood of new venture creation. 
NEJE

21,1

This study distinguishes two basic types of industry environments in which new venture is created: high-technology industry vs low-technology industry (Covin et al., 1990; Feeser and Willard, 1989; Zahra and Neubaum, 1998). A high-technology industry is characterized by high levels of business risk and velocity, fast-shifting customer preferences and shortened product life cycles (Bahrami and Evans, 1995). Compared to low-technology industries, high-technology industries present a more complex and dynamic environment, which may require additional skills and capabilities beyond that brought to the venture by the individual entrepreneur (Gartner, 1985). One such knowledge is the founding team's scientific capabilities (Deeds et al., 2000), which are deeply rooted in their domain knowledge and expertise of operating in a specific technology-driven industry. Founding teams with more domain experience (stock of domain knowledge) are more effective at exchanging and combining knowledge, leading to higher innovation (Collins and Smith, 2006). In addition, a high-technology industry is characterized by high velocity, dynamism and uncertainty. Scholars have noted that under such a scenario a highly experienced group will use significantly greater time in assessing the emerging situation but use less time in taking actions, as compared to a group with less experience (Kobus et al., 2001). This is consistent with the view from upper echelon theorists (Hambrick and Mason, 1984), who suggest that under environmental uncertainty managers' demographic characteristics are more likely to manifest in organizational outcomes. In a highly dynamic and uncertain environment, an experienced founding team possessing higher inventory of knowledge, skills and experience will be better equipped in their understanding through the entrepreneurial cognition process, and move faster in their business venturing activities.

Creating a new venture in a high-technology industry also requires a tremendous amount of social capital (Florin et al., 2003). Venture creation is a complex and unstructured process, requiring the founding team to work with stakeholders such as venture capitalists, suppliers, banks, lawyers, etc. This is especially true for entrepreneurs venturing in the knowledgeintensive and capital-intensive high-technology industry. The founders/founding team's connection to the venture capital community is critical. Well-developed venture capital networks provide tremendous incentives for entrepreneurship by lowering the difficulties of entering an industry (Florida and Kenney, 1988). Shane and Cable's (2002) field study on 50 high-technology ventures reveals that most funded venture proposals tend to come from referrals since the high-technology industry presents a higher level of information asymmetry. Studies have specially emphasized the importance of entrepreneurs' social network in the context of high-technology industry. Such social ties greatly help the entrepreneur in discovering opportunities, accessing resources and gaining legitimacy as they pursue the opportunity (e.g. Elfring and Hulsink, 2003). Therefore, based upon these arguments it is expected that in the high-technology industry the founding team's experience (industry as well as venturing) will have a greater impact on the venturing process than in a low-technology industry. This leads to the following hypotheses:

H3. The positive relationship between founding team industry experience and the likelihood of new venture creation is stronger in the high-technology industry than in the low-technology industry.

H4. The positive relationship between founding team venturing experience and the likelihood of new venture creation is stronger in the high-technology industry than in the low-technology industry.

\section{Method}

Data and sample

The theoretical model and the hypotheses were tested utilizing data from the PSED II. The PSED II is a longitudinal data set of 1,214 nascent entrepreneurs identified from a 
random digit dialing telephone survey of 31,845 households in the USA (Reynolds and Curtin, 2007). To qualify as "nascent entrepreneurs," i.e. individuals who were in the process of starting a business, respondents answered "yes" to the following three questions: Are you, alone or with others, currently trying to start a new business, including any self-employment or selling any goods or services to others? Are you, alone or with others, currently trying to start a new business or new venture for your employer, an effort that is part of your normal work? Are you, alone or with others, currently the owner of a business you help manage, including self-employment or selling any goods or services to others? In addition, respondents needed to meet three additional criteria. First, they performed some startup activities in the past 12 months. Second, they expect to own all or part of the new firm. Third, the imitative had not had a period of profitability in the past 12 months. Based on these selection criteria, the initial number of cases available for analysis was 860 .

The following procedure was used to generate the final sample. First, non-independent ventures such as purchase or takeover of an existing business, franchise or startup sponsored by existing business were eliminated. Second, since this study is interested in team-based nascent ventures, only the ventures whose founding team size is equal or greater than two, and had already been established were considered. Based on these criteria, the final sample included 446 nascent venture founding teams.

\section{Measurements}

With three follow-up rounds of data collection (the initial round and two subsequent rounds, 12 and 24 months after the initial survey), the PSED II survey allows us to investigate whether the founding team had successfully launched a new business. The dependent variable new venture creation was coded as a "1" (success) if the status of new business is reported as "operating," otherwise as a "0." The status variable was consolidated from all the three follow-up rounds (overwriting the previous status with the latest one).

Studies on entrepreneurial teams have largely suggested that founding teams' overall industry experiences have positive impact on venture performance, in view of the teams' greater level of understanding and familiarity of business environment (e.g. Boeker and Wiltbank, 2005). Similarly, team industry experience has been found to have positive relationship with venturing success (Bates, 1990). Each founding team member was asked how many years of experience did they have in the industry in which the nascent venture is in? Founding team industry experience was calculated as the mean of the years of industry experience of each team member.

Founding team venturing experience was captured by the mean of number of startups previously established by founding team members. Research suggests that prior entrepreneurship experience helps building new businesses (Krueger, 1993).

The moderator variable is the industry type, for the industry the nascent venture was being launched in. This was coded as a dummy variable for high-technology vs low-technology industry. The nascent entrepreneurs were asked the following question, "Would you consider this (new) business to be hi-tech?" The dummy variable high-technology industry was coded as " 1 " for a response as "Yes," and " 0 " for others.

Several control variables were included in the model, including average age of founding team members, founding team size and business plan development. Entrepreneurship literature has long suggested demographic characteristics of entrepreneurs such as entrepreneur age to be an important predictor of entrepreneurial outcomes (e.g. Edelman and Yli-Renko, 2010; Gartner, 1985; Shook et al., 2003). Average age of the founding team is calculated as the mean of team members' ages. Founding team size is found to be associated with new venture survival and growth (Delmar and Shane, 2006; Eisenhardt and Schoonhoven, 1990). Founding team size is measured by the head count of the founding team. Finally, scholars have argued that business plan development is an important precursor of 
NEJE

21,1

10

venture creation (Delmar and Shane, 2003; Liao and Gartner, 2006). The nascent entrepreneurs were asked whether they have formally prepared, informally written, or, unwritten a business plan. A dummy variable business plan development was created and coded as " 1 " if a business plan has been prepared or informally written, and "0" if it is unwritten.

\section{Analyses and results}

Binominal logistic regression was employed to analyze the effect of founding team experience on new venture creation. As an analytical technique, binominal logistic regression is appropriate when the dependent variable is dichotomous independent variable of any type. The technique applies maximum likelihood estimation, after transforming the dependent variable into a logit variable (the natural log of the odds of the dependent variable occurring or not). In this way, logistic regression estimates the probability of a certain event occurring (Pampel, 2000). This paper employed a hierarchical approach in analyzing both the main and interaction effects. First, a base model of logistic regression was created, which included all the control variables. Then, independent variables and moderating variables were subsequently added in the full models, in stages. The significance of the difference between the full models and the nested base model was tested by using $\chi^{2}$ tests. A significant $\chi^{2}$ test means that the additional variance of probability of persistence is explained by the added-on predictors.

Table I reports the means and standard deviations of dependent, independent, moderating and control variables and their correlations. Table II reports the results obtained from the hierarchical logistic regressions. Model 1 only included control variables.

\begin{tabular}{|c|c|c|c|c|c|c|c|c|}
\hline & Mean & SD & 1 & 2 & 3 & 4 & 5 & 6 \\
\hline 1. New venture creation & 0.61 & 0.48 & & & & & & \\
\hline 2. Average age of founding team members & 42.72 & 11.68 & $0.22 * * *$ & & & & & \\
\hline 3. High-technology industry (dummy) & 0.17 & 0.38 & 0.03 & -0.01 & & & & \\
\hline 4. Founding team size & 2.36 & 0.72 & -0.00 & 0.06 & 0.08 & & & \\
\hline 5. Business plan development (dummy) & 0.52 & 0.49 & 0.02 & 0.01 & 0.08 & 0.04 & & \\
\hline 6. Founding team industry experience & 7.83 & 8.19 & $0.22 * * *$ & $0.34 * * *$ & 0.06 & -0.03 & $0.10^{*}$ & \\
\hline 7. Founding team venturing experience & 0.31 & 0.56 & -0.02 & $0.20 * * *$ & -0.00 & $0.11 *$ & $0.10^{*}$ & 0.07 \\
\hline
\end{tabular}

Table I.

Means, standard deviations and correlations

\begin{tabular}{lccc}
\hline & Model 1 & Model 2 & Model 3 \\
\hline Intercept & -1.17 & -1.21 & -1.13 \\
Average age of founding team members & $0.04^{* * *}$ & $0.03^{* *}$ & $0.03^{* *}$ \\
High-technology industry & 0.22 & 0.16 & -0.04 \\
Founding team size & -0.06 & -0.01 & -0.04 \\
Business plan development & 0.07 & 0.02 & 0.02 \\
Founding team industry experience & & $0.05^{* * *}$ & $0.06^{* *}$ \\
Founding team venturing experience & & -0.27 & $-0.44^{*}$ \\
Founding team industry experience $\times$ high-technology industry & & & -0.03 \\
Founding team venturing experience $\times$ high-technology industry & & 446 & $1.56^{*}$ \\
Number of observations & $21.24^{* * * *}$ & $30.73^{* * *}$ & $38.56^{* * *}$ \\
Likelihood ratio $\chi^{2}$ & & $9.49^{* * *}$ & $7.83^{* * *}$ \\
$\Delta \chi^{2}$ & 0.04 & 0.07 & 0.07 \\
Pseudo $R^{2}$ & &
\end{tabular}

Table II.

Logistic regressions with robust standard errors on new venture creation

Notes: $* p<0.05 ; * * p<0.01 ; * * * p<0.001$ 
Model 2 tested the likelihood of venturing success on both control and independent Founding team variables. Model 3 tested the moderating effects of the high-technology industry dummy on the relationships between independent variables and new venture creation. The positive experience change of $\chi^{2}$ values and their significance levels confirm that adding the independent variables as well as the moderating variable helped improve the overall explanatory power of the model on the likelihood of venturing success.

$\mathrm{H1}$ predicted that founding team industry experience is positively associated with the likelihood of new venture creation. Model 2 in Table II shows that the coefficients for founding team industry experience are positive and significant $(p<0.01)$. This suggests that a founding team with higher level of industry experience has a greater probability of launching a new business. For example, Model 2 reports that the coefficient of founding team industry experience is 0.05 , indicating that the odds ratio for founding team industry experience is 1.051 . Therefore, everything else being equal, a 1 percent increase in the founding team industry experience will increase the likelihood of new venture creation by 5.1 percent. Thus, $H 1$ is strongly supported.

$H 2$ predicted that founding team venturing experience is positively associated with the likelihood of new venture creation. Model 2 in Table II reported that the coefficients for the variable founding team venturing experience are negative, and not significant. Therefore, $H 2$ was not supported.

$H 3$ predicted that the relationship between the founding team industry experience and the likelihood of new venture creation is stronger in a high-technology industry than in a low-technology industry. The results in Model 3 report the interaction effect of founding team industry experience and the high-technology industry dummy variable. The coefficient for the interaction term between founding team industry experience and the high-technology industry dummy variable is negative, and not significant (Model 3, $b=-0.03, \mathrm{~ns})$. Therefore, $H 3$ is not supported.

$\mathrm{H} 4$ predicted that the relationship between the founding team venturing experience and the likelihood of new venture creation is stronger in a high-technology industry than that in a low-technology industry. The results in Model 3 report the interaction effect of founding team venturing experience and the high-technology industry dummy variable. The coefficient for the interaction term between founding team venturing experience and the high-technology industry dummy variable was positive and significant (Model 3, $b=1.56, p<0.05$ ), suggesting that in a high-technology industry environment, the founding team venturing experience will have a greater positive impact on the likelihood of new venture creation than that in a low-technology industry environment.

Following Dawson's (2014) suggested procedure on plotting interaction effects in logit models, additional analysis was conducted. A graphical representation of the interaction effect is depicted in Figure 1.

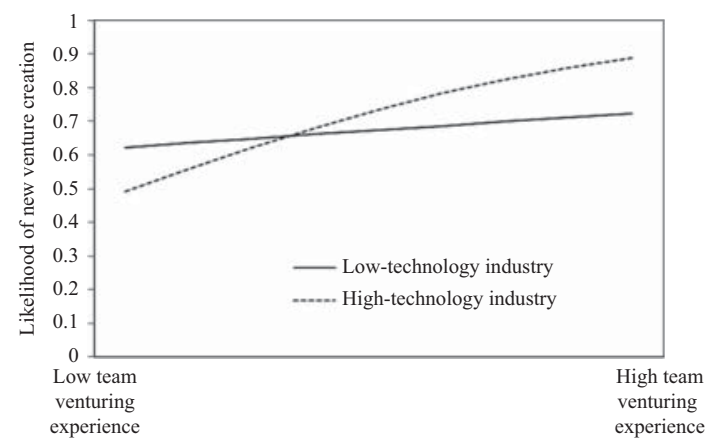

Figure 1. The moderating effect of high-technology industry 
NEJE

21,1

Figure 1 suggests that the impact of founding team venturing experience on the likelihood of new venture creation becomes greater in a high-technology industry, compared to that in a low-technology industry. As depicted in the figure, the slope of the regression line representing the high-technology industry is steeper than the one representing the low-technology industry, meaning that an increase in one unit of founding team venturing experience results more in the increase of the likelihood of new venture creation in a high-technology industry than that in a low-technology industry. This provides additional support for $H 4$.

\section{Post hoc analyses}

A post hoc analysis was conducted to increase the confidence in the findings. This post hoc analysis used the total years of industry experience of the team members to measure founding team industry experience. Similarly, to measure founding team venturing experience the total number of ventures the team members had set up prior to the present venturing initiative was used. The results were along similar lines. As predicted, founding team industry experience had a significant positive relationship with the likelihood of new venture creation $(b=0.02$, odds ratio $=1.02, p<0.01)$. The coefficient of the interaction term between founding team venturing experience and high-technology industry was positive and significant $(b=0.69, p<0.05)$, suggesting that the impact of founding team venturing experience on the likelihood of new venture creation is stronger in the high-technology industry than that in the low-technology industry. This analysis failed, however, to find a significant relationship between founding team venturing experience and the likelihood of new venture creation, as also the moderating effect of high-technology industry on the relationship between founding team industry experience and the likelihood of new venture creation.

\section{Discussion}

This study extends the current literature (e.g. Delmar and Shane, 2006; Muñoz-Bullon et al., 2015) on the impact of founding team experiences in nascent ventures. Specifically, the study fills a research gap by focusing on the team's impact on the critical and nascent venturing gestation stage, as opposed to how the founding team affects the venture post-creation. By investigating the main effects of founding team experiences (industry as well as venturing) and the interactive effect of the team experiences and industry context on the likelihood of new venture creation, this study was able to show the relative importance of these two types of experiences, and especially in high-technology industry contexts.

The study results show that founding team industry experience had a significant and positive impact on the likelihood of new venture creation. This finding is consistent with prior research, which suggests that industry experience matters in the venturing process (e.g. Delmar and Shane, 2006; Reuber and Fischer, 1999). The new venture creation process encompasses four properties: intentionality, resources, boundary and exchange (Katz and Gartner, 1988). These findings suggest that founding team industry experience likely has a positive influence on all these four aspects of the venturing process.

Surprisingly, contrary to what had hypothesized, the study found that the founding team's venturing experience did not have a significant effect on the likelihood of new venture creation. In their study, Delmar and Shane (2006) noted that the impact of a founding team's startup or venturing experience on venture survival is positive, but non-linear and subject to diminishing returns. In contrast, this study found that the founding team's venturing experience does not have a significant impact on venture creation. Similar findings exist in other studies, e.g. that founding team venturing experience has no significant influence in improving venture performance (Casson, 1987). The mixed findings suggest that additional research is needed to understand the exact 
nature of the venture creation experience and how it benefits entrepreneurial firms, Founding team pre- and post-venture gestation. In discussing the role of entrepreneurial learning, authors have noted that different types of entrepreneurs (novice, serial and portfolio) exhibit different learning behaviors, based on prior business ownership experience (Westhead et al., 2005). While prior entrepreneurship experience can bring certain assets to the founding team, it may also bring in liabilities for serial/portfolio entrepreneurs such as diminishing motivation, hubris, overconfidence or illusion of control (Simon et al., 2000; Westhead et al., 2005). Nevertheless, findings contrary to the hypothesized main effect of prior venturing experience on the likelihood of new venture creation suggest that more fine-grained analysis is needed, especially at the team level. For example, studies have shown that a "shared" venturing experience (Teal and Hofer, 2003; Zheng, 2012) or shared work experience (Roure and Maidique, 1986) among founding team members importantly affects venture outcomes.

The present study failed to find an interactive effect of high-technology industry and founding team industry experience on the likelihood of new venture creation, contrary to the prediction. This is counter to the conventional view in the field about the benefit of industry experience on entrepreneurial performance in high-technology industries (e.g. Casson, 1987). This result leads us to think further on some unique features of entrepreneurship process in a high-technology industry. The results reiterate that it is important to distinguish among the different stages of new venture development when studying the impact of founding team experience. As mentioned earlier, previous studies on founding teams have tended to examine whether and how founding teams influence the performance characteristics of a new venture, such as profitability, growth, sales, new product introduction and so on (Klotz et al., 2014). In contrast, by adopting an entrepreneurial process perspective, this study focuses on the impact of founding team experience on venture creation itself, even before the new venture is launched and finds interesting results. In doing so, this research highlights why it may be important to assess the impact of founding teams at different stages of creation of the new venture, especially before and after it is launched. Related to this, the present study also calls for greater understanding of the technology context itself. High-technology entrepreneurship is filled with "incessant novelty and innovation" and "never-ending stream of kaleidoscopic change" (Bahrami and Evans, 1995, p. 62). Existing knowledge base is made obsolete faster in a high-technology industry environment (Elfring and Hulsink, 2003). In such high-velocity environments, rigid commitments to insights from prior industry experience on the part of the founding team may even be counterproductive (Chandler and Hanks, 1994). Indeed, entrepreneurs that possessed less experience in the field's core tend to head more innovative firms (Cliff et al., 2006). Yet, scholars have argued that environmental dynamism and hostility erode managers' abilities to predict future events and their impact on organizations (Khandwalla, 1977). These factors may neutralize the positive impact of founding team industry experience on the likelihood of venture creation in a high-technology industry, thus offering support for the results.

While this study did not find a main effect interestingly, the hypothesis predicting the moderating effect of high-technology industry on the relationship between founding team venturing experience and the likelihood of new venture creation was supported. There may be a few plausible explanations for this finding. As previously noted, access to venture capital and its network is critically important for high-technology entrepreneurship (Florida and Kenney, 1988). Scholars find that prior venturing experience, even in a non-technology sector, is crucial for entrepreneurs who aim to set up a high-technology venture. This is because a prior venturing experience provides the entrepreneur knowledge to develop strategy, and build connections for acquiring funding for the development of a technology-based venture (Boussouara and Deakins, 1999). Similarly, in science-based technology ventures, entrepreneurs 
NEJE

21,1

with prior business ownership experience have broader social networks. They are, therefore, more effective in developing network ties between scientific networks and industry networks than other less-experienced entrepreneurs (Mosey and Wright, 2007).

The difference in the nature of the findings relating to the main effects as well as their interaction with the nature of industry is especially noteworthy and sets up directions for future research. Previous studies have largely tended to treat entrepreneur/founding team prior work experience as one single- or aggregative-level measure, without differentiating the potential unique roles the different types of founding team experience could play in the venturing process (e.g. Reuber and Fischer, 1999). The findings of this study suggest that founding team industry experience and venturing experience not only have different direct effect on the venturing process, but also work differently depending on the entrepreneurial context (in this case, the high-technology environment), thus influencing the likelihood of new venture creation. Studies on TMTs in entrepreneurial firms have demonstrated that different types of TMT experience may have different effects on entrepreneurial growth. Given the unique nature of the entrepreneurial overall experience, it may be important to "bundle" specific TMT experiences in order to maximize TMT effectiveness and entrepreneurial growth (Kor, 2003). Similarly, the results of this study indicate that the impact of founding team experience on new venture creation may vary with both the type of the experience and the context of venture creation. On the one hand, industry experience and venturing experience influence the venture creation process in very different ways. On the other hand, the specific entrepreneurial context (high technology vs others) influences the relationship between founding team experiences and venture creation differently. Therefore, as a direction for future research the authors suggest that future studies on founding team experience and entrepreneurial process outcomes should consider the relative importance of founding team experience, and can benefit from taking a contingency approach to examining the founding team's impact on venture creation.

\section{Conclusion}

This research extends the current literature on the importance of founding team experiences in nascent ventures (e.g. Delmar and Shane, 2006; Muñoz-Bullon et al., 2015) and makes several contributions. First, in contrast to most extant research that tended to examine the impact of founding team experience on firm outcomes post-venture creation, this study considered to what extent founding team experience affects the likelihood of the venture creation process itself. Second, the study advances the understanding of the differential roles played by different types of team experience, by teasing out the differential impact of founding team industry experience vs the founding team venturing experience. Third, this research highlighted the importance of the entrepreneurial context-in this instance, the specific context of industry (high technology vs low technology) on the relationship between founding team experience and likelihood of venture creation. Specifically, the present study noted that founding team experiences combine in interesting ways to impact the likelihood of venture creation, depending on whether the operating context is high-technology industry or not.

This study has certain limitations. The paper tested the effect of founding team experiences on venture creation rather than venture continuation (e.g. Delmar and Shane, 2003; Liao and Gartner, 2006), which means the sample represents nascent entrepreneurs who are still trying but do not have an operating business. When analyses were undertaken to include the "still trying" group as a part of the successes in the dependent variable, no significant differences in the results were found. One additional caveat of this study is that the study only relies on the number (quantity) of the ventures that individual members might have started, or the number of years of industry experience that they have had, prior 
to involving in the venturing process for creating the focal firm. Thus, and given the Founding team archival nature of the data, the study was not able to actually observe the team processes involved in utilizing these experiences (such as shared experience) to help create the venture, experience under the two types of industry contexts.

Limitations notwithstanding, the study findings indicate a number of future research opportunities. First, future researchers may consider the impact of other types of founding team experiences and their impact on new venture creation. Second, as already noted, to investigate "how" founding team experience influences the venturing process, one may need to go beyond the demographic attributes of experience and take into account the underlying team process of learning from the experience. The latter could include, for example, shared industry experience, shared venturing experience or team experience heterogeneity. Third, the process of venture creation may be an effectual process (Sarasvathy, 2001), a planned process (Shane and Delmar, 2004) or a bricolage (Baker and Nelson, 2005). The examination of the founding team experience at the nascent stage might shed light on the choice of an effective process leading to venture formation. Fourth, this study calls future research incorporating a multi-level and contingency approach in analyzing the role of founding team experience in the entrepreneurship process. Are there any specific types, or, a "bundle" of team experience that are most effective in different stages of new venture creation, and/or, under different contexts?

The findings presented in this study provide important implications for entrepreneurial practitioners. The results inform us about the importance of founding team industry experience and venturing experience in the nascent stage of the venture. The positive relationship between founding team industry experience and new venture creation suggests that the founding team should include more members with higher level of industry experience. In addition, in a high-technology industry, the founding team's venturing experience becomes even more salient, in terms of its impact on the venturing process. Therefore, a team with higher levels of prior venturing experience (does not matter whether it was in a high-technology sector or not) is critical for the success of the new venture being created. In effect, developing a nuanced understanding of the different types of founding team experience, and the effect of such team experience in the operating industry context is critically important to team assembling and organizing for the successful launch of new ventures.

\section{References}

Alvarez, S.A. and Busenitz, L.W. (2001), "The entrepreneurship of resource-based theory", Journal of Management, Vol. 27 No. 6, pp. 755-775.

Amason, A.C., Shrader, R.C. and Tompson, G.H. (2006), "Newness and novelty: relating top management team composition to new venture performance", Journal of Business Venturing, Vol. 21 No. 1, pp. 125-148.

Bahrami, H. and Evans, S. (1995), "Flexible re-cycling and high-technology entrepreneurship", California Management Review, Vol. 37 No. 3, pp. 62-89.

Baker, T. and Nelson, R.E. (2005), "Creating something from nothing: resource construction through entrepreneurial bricolage", Administrative Science Quarterly, Vol. 50 No. 3, pp. 329-366.

Baron, R.A. (2008), "The role of affect in the entrepreneurial process", Academy of Management Review, Vol. 33 No. 2, pp. 328-340.

Baron, R.A. and Ensley, M.D. (2006), "Opportunity recognition as the detection of meaningful patterns: evidence from comparisons of novice and experienced entrepreneurs", Management Science, Vol. 52 No. 9, pp. 1331-1344.

Bates, T. (1990), "Entrepreneur human capital inputs and small business longevity", The Review of Economics and Statistics, Vol. 72 No. 4, pp. 551-559. 
NEJE

21,1

Becker, G.S. (1962), "Investment in human capital: a theoretical analysis", Journal of Political Economy, Part 2, Vol. 70 No. 5, pp. 9-49.

Beckman, C.M., Burton, M.D. and O'reilly, C. (2007), "Early teams: the impact of team demography on VC financing and going public", Journal of Business Venturing, Vol. 22 No. 2, pp. 147-173.

Blatt, R. (2009), "Tough love: how communal schemas and contracting practices build relational capital in entrepreneurial teams", Academy of Management Review, Vol. 34 No. 3, pp. 533-551.

Boeker, W. and Wiltbank, R. (2005), "New venture evolution and managerial capabilities", Organization Science, Vol. 16 No. 2, pp. 123-133.

Boussouara, M. and Deakins, D. (1999), "Market-based learning, entrepreneurship and the high technology small firm”, International Journal of Entrepreneurial Behavior \& Research, Vol. 5 No. 4, pp. 204-223.

Brush, C.G., Greene, P.G. and Hart, M.M. (2001), "From initial idea to unique advantage: the entrepreneurial challenge of constructing a resource base", Academy of Management Executive, Vol. 15 No. 1, pp. 64-78.

Burt, R.S. (2009), Structural Holes: The Social Structure of Competition, Harvard University Press, Cambridge, MA, and London.

Busenitz, L.W. and Barney, J.B. (1997), "Differences between entrepreneurs and managers in large organizations: biases and heuristics in strategic decision-making", Journal of Business Venturing, Vol. 12 No. 1, pp. 9-30.

Casson, M. (1987), The Firm and the Market: Studies on Multinational Enterprise and the Scope of the Firm, MIT Press, Cambridge, MA.

Chandler, G.N. (1996), "Business similarity as a moderator of the relationship between pre-ownership experience and venture performance", Entrepreneurship Theory and Practice, Vol. 20 No. 3, pp. 51-65.

Chandler, G.N. and Hanks, S.H. (1994), "Founder competence, the environment, and venture performance", Entrepreneurship Theory and Practice, Vol. 18 No. 3, pp. 77-89.

Chandler, G.N. and Jansen, E. (1992), "The founder's self-assessed competence and venture performance", Journal of Business Venturing, Vol. 7 No. 3, pp. 223-236.

Chowdhury, S. (2005), "Demographic diversity for building an effective entrepreneurial team: is it important?", Journal of Business Venturing, Vol. 20 No. 6, pp. 727-746.

Cliff, J.E., Jennings, P.D. and Greenwood, R. (2006), "New to the game and questioning the rules: the experiences and beliefs of founders who start imitative versus innovative firms", Journal of Business Venturing, Vol. 21 No. 5, pp. 633-663.

Collins, C.J. and Smith, K.G. (2006), "Knowledge exchange and combination: the role of human resource practices in the performance of high-technology firms", Academy of Management Journal, Vol. 49 No. 3, pp. 544-560.

Colombo, M.G. and Grilli, L. (2005), "Founders' human capital and the growth of new technology-based firms: a competence-based view", Research Policy, Vol. 34 No. 6, pp. 795-816.

Cooper, A.C., Gimeno-Gascon, F.J. and Woo, C.Y. (1994), "Initial human and financial capital as predictors of new venture performance”, Journal of Business Venturing, Vol. 9 No. 5, pp. 371-395.

Covin, J.G., Slevin, D.P. and Covin, T.J. (1990), "Content and performance of growth-seeking strategies: a comparison of small firms in high-and low technology industries", Journal of Business Venturing, Vol. 5 No. 6, pp. 391-412.

Dawson, J.F. (2014), "Moderation in management research: what, why, when, and how", Journal of Business and Psychology, Vol. 29 No. 1, pp. 1-19.

Deeds, D.L., Decarolis, D. and Coombs, J. (2000), "Dynamic capabilities and new product development in high technology ventures: an empirical analysis of new biotechnology firms", Journal of Business Venturing, Vol. 15 No. 3, pp. 211-229.

Delmar, F. and Shane, S. (2003), "Does business planning facilitate the development of new ventures?", Strategic Management Journal, Vol. 24 No. 12, pp. 1165-1185. 
Delmar, F. and Shane, S. (2006), "Does experience matter? The effect of founding team experience Founding team on the survival and sales of newly founded ventures", Strategic Organization, Vol. 4 No. 3, pp. 215-247.

Dew, N., Read, S., Sarasvathy, S.D. and Wiltbank, R. (2009), "Effectual versus predictive logics in entrepreneurial decision-making: differences between experts and novices", Journal of Business Venturing, Vol. 24 No. 4, pp. 287-309.

Duchesneau, D.A. and Gartner, W.B. (1990), "A profile of new venture success and failure in an emerging industry”, Journal of Business Venturing, Vol. 5 No. 5, pp. 297-312.

Eckhardt, J.T., Shane, S. and Delmar, F. (2006), "Multistage selection and the financing of new ventures", Management Science, Vol. 52 No. 2, pp. 220-232.

Edelman, L. and Yli-Renko, H. (2010), "The impact of environment and entrepreneurial perceptions on venture-creation efforts: bridging the discovery and creation views of entrepreneurship", Entrepreneurship Theory and Practice, Vol. 34 No. 5, pp. 833-856.

Eisenhardt, K.M. and Schoonhoven, C.B. (1990), "Organizational growth: linking founding team, strategy, environment, and growth among US semiconductor ventures, 1978-1988", Administrative Science Quarterly, Vol. 35 No. 3, pp. 504-529.

Elfring, T. and Hulsink, W. (2003), "Networks in entrepreneurship: the case of high-technology firms", Small Business Economics, Vol. 21 No. 4, pp. 409-422.

Ensley, M.D. and Hmieleski, K.A. (2005), "A comparative study of new venture top management team composition, dynamics and performance between university-based and independent start-ups", Research Policy, Vol. 34 No. 7, pp. 1091-1105.

Ensley, M.D., Hmieleski, K.M. and Pearce, C.L. (2006), "The importance of vertical and shared leadership within new venture top management teams: Implications for the performance of startups", Leadership Quarterly, Vol. 17 No. 3, pp. 217-231.

Ensley, M.D., Pearson, A.W. and Amasone, A.C. (2002), "Understanding the dynamics of new venture top management teams - cohesion, conflict, and new venture performance", Journal of Business Venturing, Vol. 17 No. 4, pp. 365-386.

Feeser, H.R. and Willard, G.E. (1989), "Incubators and performance: a comparison of high- and low-growth high-tech firms", Journal of Business Venturing, Vol. 4 No. 6, pp. 429-442.

Fern, M.J., Cardinal, L.B. and O'neill, H.M. (2012), "The genesis of strategy in new ventures: escaping the constraints of founder and team knowledge", Strategic Management Journal, Vol. 33 No. 4, pp. 427-447.

Florida, R. and Kenney, M. (1988), "Venture capital and high technology entrepreneurship", Journal of Business Venturing, Vol. 3 No. 4, pp. 301-319.

Florin, J., Lubatkin, M. and Schulze, W. (2003), “A social capital model of high-growth ventures", Academy of Management Journal, Vol. 46 No. 3, pp. 374-384.

Forbes, D.P. (1999), "Cognitive approaches to new venture creation", International Journal of Management Reviews, Vol. 1 No. 4, pp. 415-439.

Forbes, D.P. (2005), "The effects of strategic decision making on entrepreneurial self-efficacy", Entrepreneurship Theory and Practice, Vol. 29 No. 5, pp. 599-626.

Gartner, W.B. (1985), "A conceptual framework for describing the phenomenon of new venture creation”, Academy of Management Review, Vol. 10 No. 4, pp. 696-706.

Gartner, W.B. and Shaver, K.G. (2012), "Nascent entrepreneurship panel studies: progress and challenges”, Small Business Economics, Vol. 39 No. 3, pp. 659-665.

Gartner, W.B., Bird, B.J. and Starr, J.A. (1992), "Acting as if: differentiating entrepreneurial from organizational behavior", Entrepreneurship Theory and Practice, Vol. 16 No. 3, pp. 13-32.

Gimeno, J., Folta, T.B., Cooper, A.C. and Woo, C.Y. (1997), "Survival of the fittest? Entrepreneurial human capital and the persistence of underperforming firms", Administrative Science Quarterly, Vol. 42 No. 4, pp. 750-783. 
NEJE

21,1

Grégoire, D.A., Barr, P.S. and Shepherd, D.A. (2010), "Cognitive processes of opportunity recognition: the role of structural alignment”, Organization Science, Vol. 21 No. 2, pp. 413-431.

Grégoire, D.A., Corbett, A.C. and McMullen, J.S. (2011), “The cognitive perspective in entrepreneurship: an agenda for future research", Journal of Management Studies, Vol. 48 No. 6, pp. 1443-1477.

Gruber, M., MacMillan, I.C. and Thompson, J.D. (2012), "From minds to markets: how human capital endowments shape market opportunity identification of technology start-ups", Journal of Management, Vol. 38 No. 5, pp. 1421-1449.

Hambrick, D.C. and Mason, P.A. (1984), "Upper echelons: the organization as a reflection of its top managers", Academy of Management Review, Vol. 9 No. 2, pp. 193-206.

Hmieleski, K.M. and Baron, R.A. (2009), "Entrepreneurs' optimism and new venture performance: a social cognitive perspective", Academy of Management Journal, Vol. 52 No. 3, pp. 473-488.

Hmieleski, K.M. and Ensley, M.D. (2007), “A contextual examination of new venture performance: entrepreneur leadership behavior, top management team heterogeneity, and environmental dynamism", Journal of Organizational Behavior, Vol. 28 No. 7, pp. 865-889.

Hsu, D.H. (2004), “What do entrepreneurs pay for venture capital affiliation?”, The Journal of Finance, Vol. 59 No. 4, pp. 1805-1844.

Hsu, D.H. (2007), "Experienced entrepreneurial founders, organizational capital, and venture capital funding", Research Policy, Vol. 36 No. 5, pp. 722-741.

Jin, L.L., Madison, K., Kraiczy, N.D., Kellermanns, F.W., Crook, T.R. and Xi, J. (2017), "Entrepreneurial team composition characteristics and new venture performance: a meta-analysis", Entrepreneurship Theory and Practice, Vol. 41 No. 5, pp. 743-771.

Kamm, J.B., Shuman, J.C., Seeger, J.A. and Nurick, A.J. (1990), "Entrepreneurial teams in new venture creation: a research agenda", Entrepreneurship Theory and Practice, Vol. 14 No. 4, pp. 7-17.

Katz, J. and Gartner, W.B. (1988), "Properties of emerging organizations", Academy of Management Review, Vol. 13 No. 3, pp. 429-441.

Khandwalla, P.N. (1977), The Design of Organizations, Harcourt Brace Jovanovich, New York, NY.

Kirzner, I.M. (1979), Perception, Opportunity, and Profit, University of Chicago Press, Chicago, IL.

Klotz, A.C., Hmieleski, K.M., Bradley, B.H. and Busenitz, L.W. (2014), "New venture teams: a review of the literature and roadmap for future research", Journal of Management, Vol. 40 No. 1, pp. 226-255.

Kobus, D.A., Proctor, S. and Holste, S. (2001), "Effects of experience and uncertainty during dynamic decision making", International Journal of Industrial Ergonomics, Vol. 28 No. 5, pp. 275-290.

Kor, Y.Y. (2003), "Experience-based top management team competence and sustained growth", Organization Science, Vol. 14 No. 6, pp. 707-719.

Kor, Y.Y., Mahoney, J.T. and Michael, S.C. (2007), "Resources, capabilities and entrepreneurial perceptions", Journal of Management Studies, Vol. 44 No. 7, pp. 1187-1212.

Krueger, N. (1993), "The impact of prior entrepreneurial exposure on perceptions of new venture feasibility and desirability", Entrepreneurship Theory and Practice, Vol. 18 No. 1, pp. 5-21.

Lechler, T. (2001), "Social interaction: a determinant of entrepreneurial team venture success", Small Business Economics, Vol. 16 No. 4, pp. 263-278.

Liao, J. and Gartner, W.B. (2006), "The effects of pre-venture plan timing and perceived environmental uncertainty on the persistence of emerging firms", Small Business Economics, Vol. 27 No. 1, pp. 23-40.

Lumpkin, G.T. and Dess, G.G. (2001), "Linking two dimensions of entrepreneurial orientation to firm performance: the moderating role of environment and industry life cycle", Journal of Business Venturing, Vol. 16 No. 5, pp. 429-451.

McMullen, J.S. and Shepherd, D.A. (2006), "Entrepreneurial action and the role of uncertainty in the theory of the entrepreneur", Academy of Management Review, Vol. 31 No. 1, pp. 132-152. 
MacMillan, I.C., Siegel, R. and Narasimha, P.S. (1985), "Criteria used by venture capitalists to evaluate Founding team new venture proposals", Journal of Business Venturing, Vol. 1 No. 1, pp. 119-128.

March, J.G. and Simon, H.A. (1958), Organizations, Wiley, New York, NY.

Mitchell, R.K., Busenitz, L., Lant, T., Mcdougall, P.P., Morse, E.A. and Smith, J.B. (2002), “Toward a theory of entrepreneurial cognition: rethinking the people side of entrepreneurship research", Entrepreneurship Theory and Practice, Vol. 27 No. 2, pp. 93-104.

Mitchell, R.K., Busenitz, L.W., Bird, B., Marie Gaglio, C., McMullen, J.S., Morse, E.A. and Smith, J.B. (2007), "The central question in entrepreneurial cognition research 2007", Entrepreneurship Theory and Practice, Vol. 31 No. 1, pp. 1-27.

Morris, M.H. (2015), Entrepreneurship as Experience, Wiley Online Library, available at: https://doi.org/ 10.1002/9781118785317.weom030039

Morris, M.H., Kuratko, D.F., Schindehutte, M. and Spivack, A.J. (2012), "Framing the entrepreneurial experience", Entrepreneurship Theory and Practice, Vol. 36 No. 1, pp. 11-40.

Mosey, S. and Wright, M. (2007), "From human capital to social capital: a longitudinal study of technology-based academic entrepreneurs", Entrepreneurship Theory and Practice, Vol. 31 No. 6, pp. 909-935.

Muñoz-Bullon, F., Sanchez-Bueno, M.J. and Vos-Saz, A. (2015), "Startup team contributions and new firm creation: the role of founding team experience", Entrepreneurship \& Regional Development, Vol. 27 Nos 1/2, pp. 80-105.

Norton, W.I. and Moore, W.T. (2006), "The influence of entrepreneurial risk assessment on venture launch or growth decisions", Small Business Economics, Vol. 26 No. 3, pp. 215-226.

Pampel, F.C. (2000), Logistic Regression: A Primer (Quantitative Applications in the Social Sciences), Sage Publications, London.

Patzelt, H., Knyphausen-Aufsess, D.Z. and Nikol, P. (2008), “Top management teams, business models, and performance of biotechnology ventures: an upper echelon perspective", British Journal of Management, Vol. 19 No. 3, pp. 205-221.

Perry, J.T., Chandler, G.N., Yao, X. and Pett, T.L. (2011), "Founder characteristics and legitimacy-seeking behaviors", New England Journal of Entrepreneurship, Vol. 14 No. 2, pp. 41-51.

Porter, M.E. (1985), Competitive Advantage: Creating and Sustaining Superior Performance. 1985, Free Press, New York, NY.

Rasmussen, E., Mosey, S. and Wright, M. (2011), "The evolution of entrepreneurial competencies: a longitudinal study of university spin-off venture emergence", Journal of Management Studies, Vol. 48 No. 6, pp. 1314-1345.

Reuber, A.R. and Fischer, E. (1999), "Understanding the consequences of founders' experience”, Journal of Small Business Management, Vol. 37 No. 2, pp. 30-45.

Reuber, A.R. and Fischer, E.M. (1994), "Entrepreneurs' experience, expertise, and the performance of technology-based firms", IEEE Transactions on Engineering Management, Vol. 41 No. 4, pp. 365-374.

Reynolds, P.D. and Curtin, R. (2007), "Panel Study of Entrepreneurial Dynamics II: Data overview", Kauffman Symposium on Entrepreneurship and Innovation Data, November 2, available at: https://ssrn.com/abstract=1023086; http://dx.doi.org/10.2139/ssrn.1023086

Roure, J.B. and Maidique, M.A. (1986), "Linking prefunding factors and high-technology venture success: an exploratory study", Journal of Business Venturing, Vol. 1 No. 3, pp. 295-306.

Sandner, P., Block, J. and Lutz, A. (2008), "Determinants of success of subsidized start-ups in Germany-an empirical analysis”, Zeitschrift für Betriebswirtschaft, Vol. 78 Nos 7/8, pp. 753-777, available at: https://ssrn.com/abstract $=998818$

Sarasvathy, S.D. (2001), "Causation and effectuation: toward a theoretical shift from economic inevitability to entrepreneurial contingency", Academy of Management Review, Vol. 26 No. 2, pp. 243-263. 
NEJE

21,1

Shane, S. and Cable, D. (2002), "Network ties, reputation, and the financing of new ventures", Management Science, Vol. 48 No. 3, pp. 364-381.

Shane, S. and Delmar, F. (2004), "Planning for the market: business planning before marketing and the continuation of organizing efforts", Journal of Business Venturing, Vol. 19 No. 6, pp. 767-785.

Shane, S. and Khurana, R. (2003), "Bringing individuals back in: the effects of career experience on new firm founding", Industrial and Corporate Change, Vol. 12 No. 3, pp. 519-543.

Shane, S. and Stuart, T. (2002), "Organizational endowments and the performance of university startups”, Management Science, Vol. 48 No. 1, pp. 154-170.

Shane, S. and Venkataraman, S. (2000), "The promise of entrepreneurship as a field of research", Academy of Management Review, Vol. 25 No. 1, pp. 217-226.

Shaver, K.G. and Scott, L.R. (1992), "Person, process, choice: the psychology of new venture creation", Entrepreneurship Theory and Practice, Vol. 16 No. 2, pp. 23-46.

Shepherd, D.A. and Detienne, D.R. (2005), "Prior knowledge, potential financial reward, and opportunity identification”, Entrepreneurship Theory and Practice, Vol. 29 No. 1, pp. 91-112.

Shook, C.L., Priem, R.L. and Mcgee, J.E. (2003), "Venture creation and the enterprising individual: a review and synthesis", Journal of Management, Vol. 29 No. 3, pp. 379-399.

Simon, H.A. (1979), "Rational decision making in business organizations", The American Economic Review, Vol. 69 No. 4, pp. 493-513.

Simon, M., Houghton, S.M. and Aquino, K. (2000), "Cognitive, biases, risk perception and venture formation: how individuals decide to start companies", Journal of Business Venturing, Vol. 15 No. 2, pp. 113-134.

Stinchcombe, A.L. and March, J.G. (1965), "Social structure and organizations", in March, J.D. (Ed.), Handbook of Organizations, Rand McNally, Chicago, Vol. 7, pp. 142-193.

Swaminathan, A. (1996), "Environmental conditions at founding and organizational mortality: a trial-by-fire model", Academy of Management Journal, Vol. 39 No. 5, pp. 1350-1377.

Tang, J., Kacmar, K.M.M. and Busenitz, L. (2012), "Entrepreneurial alertness in the pursuit of new opportunities", Journal of Business Venturing, Vol. 27 No. 1, pp. 77-94.

Teal, E.J. and Hofer, C.W. (2003), "The determinants of new venture success: strategy, industry structure, and the founding entrepreneurial team”, The Journal of Private Equity, Vol. 6 No. 4, pp. 38-51.

Ucbasaran, D., Alsos, G.A., Westhead, P. and Wright, M. (2008), “Habitual entrepreneurs”, Foundations and Trends in Entrepreneurship, Vol. 4 No. 4, pp. 309-450.

Wasserman, N. (2003), "Founder-CEO succession and the paradox of entrepreneurial success", Organization Science, Vol. 14 No. 2, pp. 149-172.

West, G.P. and Noel, T.W. (2009), "The impact of knowledge resources on new venture performance", Journal of Small Business Management, Vol. 47 No. 1, pp. 1-22.

Westhead, P., Ucbasaran, D. and Wright, M. (2005), "Experience and cognition: do novice, serial and portfolio entrepreneurs differ?”, International Small Business Journal, Vol. 23 No. 1, pp. 72-98.

Westhead, P., Ucbasaran, D. and Wright, M. (2009), "Information search and opportunity identification: the importance of prior business ownership experience", International Small Business Journal, Vol. 27 No. 6, pp. 659-680.

Wright, M., Westhead, P. and Sohl, J. (1998), "Editors' introduction: habitual entrepreneurs and angel investors", Entrepreneurship Theory and Practice, Vol. 22 No. 4, pp. 5-22.

Zahra, S.A. and Neubaum, D.O. (1998), "Environmental adversity and the entrepreneurial activities of new ventures", Journal of Developmental Entrepreneurship, Vol. 3 No. 2, pp. 123-140.

Zhao, H., Seibert, S.E. and Hills, G.E. (2005), "The mediating role of self-efficacy in the development of entrepreneurial intentions", Journal of Applied Psychology, Vol. 90 No. 6, pp. 1265-1272. 
Zhao, Y.L., Song, M. and Storm, G.L. (2013), "Founding team capabilities and new venture performance: Founding team the mediating role of strategic positional advantages", Entrepreneurship Theory and Practice, Vol. 37 No. 4, pp. 789-814.

Zheng, Y.F. (2012), "Unlocking founding team prior shared experience: a transactive memory system perspective”, Journal of Business Venturing, Vol. 27 No. 5, pp. 577-591.

Zheng, Y.F., Devaughn, M.L. and Zellmer-Bruhn, M. (2016), "Shared and shared alike? Founders' prior shared experience and performance of newly founded banks", Strategic Management Journal, Vol. 37 No. 12, pp. 2503-2520.

Zhou, W.C., Hu, H.J. and Zey, M. (2015), "Team composition of new venture founding teams: does personality matter?", International Journal of Entrepreneurial Behaviour \& Research, Vol. 21 No. 5, pp. 673-689.

\section{Corresponding author}

Jun Li can be contacted at: jun.li@unh.edu

For instructions on how to order reprints of this article, please visit our website: 